\title{
Anti-Tumor Promoting Activities of Edible Plants against Okadaic Acid
}

\author{
Akihiro OHARA and Tsugio MATSUHISA \\ Department of Applied Biological Chemistry, Faculty of Agriculture, Meijo University, 1-501, Shiogamaguchi, Tempaku-ku, Nagoya, 468-8502, \\ Japan
}

Received October 19, 2001; Accepted January 29, 2002

\begin{abstract}
The anti-tumor promoting activities of 120 kinds of edible plants against the non TPA-type promoter, okadaic acid (OA), were investigated by measuring suppression of the inhibitory effect of OA on protein phosphatase-2A (PP2A), since OA promotes tumor formation by inhibiting this enzyme. One quarter of the tested samples showed activity over $20 \%$. In particular, 8 kinds of plants (basil (100\%), peppermint (100\%), carrot leaf (100\%), broccoli $(\mathbf{1 0 0 \%})$, nabana $(\mathbf{9 8 \%})$, edible burdock $(\mathbf{8 6 \%})$, watermelon $(\mathbf{9 9 \%})$ and winter fungus $(\mathbf{1 0 0 \%}))$ showed very strong activity. Physicochemical properties of the active components contained in the samples that showed high activity were found that the active component in the major sample was inactivated by cold storage or boiling, and that only edible burdock showed strong activity following both types of processing. Soluble fractions from these samples were obtained by extraction in hexane, benzene, ethyl acetate, methanol and water. Very strong anti-OA activity was observed in water soluble extracts of edible burdock and eggplant, whereas cabbage and broccoli showed activity in the extraction fractions in organic solvents such as hexane. Although the active components in these samples were not identified, these findings suggest that the component with anti-okadaic acid activity must be present in edible plants.
\end{abstract}

Keywords: okadaic acid, anti-tumor promoting activity, protein phosphatase-2A (PP2A), edible plants, edible burdock

Seventy percent of the causes of carcinogenesis are related to food and smoking (Nakamura et al., 1990). Carcinogens derived from smoking can be avoided by stopping the habit of smoking; however it is difficult to avoid the carcinogens consumed in daily foods. It is known that many carcinogens and/or mutagens, such as heterocyclic amines (Sugimura, 1995) or $\mathrm{N}$-nitoroso compounds (Ohara et al., 1988), are present in food, although evidence that some foods actually prevent cancer has also been reported (Osawa, 1995, 1999; Watanabe et al., 1997).

Cancer develops through a multistep process (Sugimura, 1982). The first stage of carcinogenesis is caused by chemical compounds called initiators. The initiation signifies a gene mutation, and a normal cell becomes a precancerous cell. Most mutagens are also carcinogens. Therefore, antimutagenic properties are sought in various compounds as potential inhibitors of initiations, and much information on this has been accumulated (Natake et al., 1989; Kanazawa et al., 1995; Samejima et al., 1995; Ohara \& Hiramatsu, 1997; Ohara \& Takehara, 1997; Ohara et al., 2000).

The second stage of cancer development is promotion, in which the precancerous cell becomes a cancer cell. This stage is a reversible phenomenon, however, and it is very important to suppress this step to prevent cancer. Promotion is caused by a promoter compound such as TPA (12- $O$-tetradecanoylphorbol13-acetate), but there are many reports of anti-tumor promoting activity against TPA (Koshimizu, 1995, 1996; Ohigashi et al., 1997). There are, however, many promoters which operate via different mechanisms. One of them is okadaic acid (OA) which is also known as a diarrhetic shellfish poison, and as a PP2A (protein phosphatase type-2A) inhibitor (Fujiki, 1992). OA accelerates carcinogenesis in the liver and many other organs, while TPA promotes only cutaneous cancer (Matias et al., 1999; Fujiki \& Suganuma, 1999; Traore et al., 2000). There is thus a strong possibility of suppressing the promotion process of carcinogenesis on the material which inhibits the OA. There have been only a few reports on OA (Murata et al., 1982; Suganuma \& Fujiki, 1993).

Here, we searched for anti-OA activity in 120 edible plants, and examined all properties of the active ingredients.

\section{Materials and Methods}

Materials The 120 edible plants examined were general commercial products. Okadaic acid was purchased from Wako Pure Chemical Ind. Ltd. $p$-Nitro phenylphosphate ( $p$-NPP) was purchased from Sigma-Aldrich Fine Chemicals (USA), and PP2A was from Upstate Biotechnology (USA). All other chemicals were of high grade.

Extracts from edible plants The water extract from each sample was obtained with a juice mixer. The sample solution was filtered to eliminate bacteria, then it was used for the experiment on anti-OA activity.

Anti-OA activity PP2A is inhibited by OA, and since the substrate specificity is low, various phosphates are hydrolyzed by PP2A. Based on this property, a simple testing method was established for PP2A in which $p$-NPP was the substrate (Takai \& Mieskes, 1991, Takai et al., 1992). Using this method, Ogino et al. (1997) proposed a method of measuring anti-OA. On samples which inhibited the tumor promoter, OA, a strong possibility was found of preventing the cancer. The inhibition ratio of the sample solution against okadaic acid was measured against an index.

Unless otherwise stated, PP2A was diluted with a buffer containing $40 \mathrm{~mm}$-Tris/ $\mathrm{HCl}, 20 \mathrm{mM}-\mathrm{KCl}, 30 \mathrm{mM}-\mathrm{MgCl}_{2}$ and $2 \mathrm{mM}-$ 
DL-dithiothreitol ( $\mathrm{pH} \mathrm{8.1)}$ and $1 \mathrm{mg}$ of $\mathrm{BSA} / \mathrm{ml}$. Okadaic acid was dissolved in dimethyl sulfoxide (DMSO) to give a $10 \mathrm{mM}$ solution and diluted in this buffer. The maximal concentration of DMSO in the reaction mixture was $0.01 \%(\mathrm{v} / \mathrm{v})$. Control activities were not significantly affected by addition of this amount of DMSO.

The sample solution was incubated with an OA solution for 20 min (reaction mixture). Thereafter, to assay anti-OA activity, reaction was started by adding $\mathrm{PP} 2 \mathrm{~A}$ to a micro tube containing $p$-NPP and the reaction mixture. The sample was incubated for $60 \mathrm{~min}$ and absorbance of the mixture was measured at $405 \mathrm{~nm}$. All procedures were carried out at $30^{\circ} \mathrm{C}$.

By deducting the amount absorbed by the sample solution, the effect of the absorption by the sample was excluded. Also, on the samples which showed anti-OA activity, it was determined whether or not the similar action with PP2A existed.

Anti-OA activity was classified into 4 levels by comparison with the control:

Very strong (++): Enzyme inhibition of OA suppressed over $80 \%$.

Strong (+): OA suppressed from $40 \%$ to $79 \%$.

Weak ( \pm ): OA suppressed from $20 \%$ to $39 \%$.

None (-): OA suppressed to below than $19 \%$.

\section{Results and Discussion}

Anti-OA activity The anti-OA activity in the water extracts of 120 edible plants was measured (Table 1). Eight types (7\%) of plants showed very strong activity (++) with over an $80 \%$ inhibition ratio against $\mathrm{OA}$. Specifically, these sample solutions showed the following activities: basil (100\%), peppermint $(100 \%)$, carrot leaf $(100 \%)$, broccoli $(100 \%)$, nabana $(98 \%)$, edible burdock (86\%), watermelon $(99 \%)$ and winter fungus (100\%). Sixteen types (14\%) of tested plants including turnip (47\%), cauliflower (67\%), agar-agar (41\%), cherry (58\%), bitter gourd (43\%) and chestnuts (51\%) showed strong activity (+) of less than $80 \%$ but over $40 \%$ inhibition ratio, and eight types $(7 \%)$ of plants showed weak activity $( \pm$ ) of under $40 \%$ but over $20 \%$ inhibition ratio.

Therefore, one quarter of the tested plants suppressed the tumor promoter, okadaic acid. These samples showed that antiOA activity might prevent the carcinogenesis. Overall, these findings show similar trends as in the reports of anti tumor-promoter activity against TPA, another type of tumor promoter (Koshimizu, 1995, 1996; Ohigashi, et al., 1997), although the activity in each sample is different.

Physicochemical properties of the active component The physicochemical properties of the components of samples showing strong anti-OA activity were examined. For one week to determine stability of the active components in a refrigerator $\left(4^{\circ} \mathrm{C}\right)$, as shown in Table 2 , only burdock maintained the same level of activity (100\%) as before. Basil still showed weak activity $(38 \%)$, but the other plants lost activity even in cold storage.

The change in activity following heat treatment at $100^{\circ} \mathrm{C}$ for 5 min was also evaluated and, as shown in Table 3, edible burdock

Table 2. Change in anti-OA activity by low temperature storage.

\begin{tabular}{lcc}
\hline & Fresh & 1 week \\
\hline Basil & ++ & \pm \\
Peppermint & ++ & - \\
Broccoli & ++ & - \\
Tomyo & + & - \\
Edible burdock & ++ & ++ \\
Watermelon & ++ & - \\
Winter fungus & ++ & - \\
Oyster mushrooms & + & - \\
Cultivated mushrooms & + & - \\
\hline Anti-OA activity, Very strong $(++):$ & over $80 \%$, Strong $(+):$ from $40 \%$ to
\end{tabular}

Anti-OA activity, Very strong (++): over $80 \%$, Strong $(+)$ : from $40 \%$ to $79 \%$, Weak $( \pm)$ : from $20 \%$ to $39 \%$, None (-): less than $19 \%$.

Table 1. Anti-OA activities of edible plants.

\begin{tabular}{|c|c|c|c|c|c|}
\hline Activity & & & Samples & & \\
\hline++ & $\begin{array}{l}\text { Basil } \\
\text { Nabana }\end{array}$ & $\begin{array}{l}\text { Peppermint } \\
\text { Watermelon }\end{array}$ & $\begin{array}{l}\text { Carrot leaf } \\
\text { Winter fungus }\end{array}$ & Edible burdock & Broccoli \\
\hline+ & $\begin{array}{l}\text { Tomyo } \\
\text { White gourd } \\
\text { Chestnut } \\
\text { Agar-agar }\end{array}$ & $\begin{array}{l}\text { Cabbage } \\
\text { Balsam pear } \\
\text { Tree tomato }\end{array}$ & $\begin{array}{l}\text { Ashitaba } \\
\text { Pumpkin } \\
\text { Oyster mushroom }\end{array}$ & $\begin{array}{l}\text { Turnip } \\
\text { Cherry } \\
\text { Cultivated mushroom }\end{array}$ & $\begin{array}{l}\text { Cauliflower } \\
\text { Pear } \\
\text { Hen of the wood }\end{array}$ \\
\hline \pm & $\begin{array}{l}\text { Komatsuna } \\
\text { Garden pea }\end{array}$ & $\begin{array}{l}\text { Spinach } \\
\text { Pomegranate }\end{array}$ & $\begin{array}{l}\text { Pak-choi } \\
\text { Kiwi fruits }\end{array}$ & Perilla & Eggplant \\
\hline- & $\begin{array}{l}\text { Celery } \\
\text { Japanese horwort } \\
\text { Sunny letucce } \\
\text { Vitamin-na } \\
\text { Asparagus } \\
\text { Onion } \\
\text { Bamboo shoot } \\
\text { Carrot } \\
\text { Cucumber } \\
\text { Potato } \\
\text { Bean sprouts } \\
\text { Unshiu orange } \\
\text { Sudachi } \\
\text { Grapefruit } \\
\text { Grape (kyohou) } \\
\text { Banana } \\
\text { Hiziki }\end{array}$ & $\begin{array}{l}\text { Chicory } \\
\text { Radish leaf } \\
\text { Red malabar nightshade } \\
\text { Himawari-na } \\
\text { Bracken } \\
\text { Petty onion } \\
\text { Barnboo shoot (menma) } \\
\text { Ginger } \\
\text { Sweet pepper } \\
\text { Sweet potato } \\
\text { Kidney bean } \\
\text { Navel } \\
\text { Yuzu } \\
\text { Apple } \\
\text { Strawberry } \\
\text { Matsutake } \\
\text { Kombu }\end{array}$ & $\begin{array}{l}\text { Chinese cabbage } \\
\text { Nanjaku-hasai } \\
\text { Water-cress } \\
\text { Chinese mustard } \\
\text { Leek } \\
\text { Red onion } \\
\text { Radish } \\
\text { Myoga } \\
\text { Paprika } \\
\text { Taro } \\
\text { Soy bean } \\
\text { Litchi } \\
\text { Lemon } \\
\text { European pear } \\
\text { Blueberry } \\
\text { Nameko } \\
\text { Woody ear }\end{array}$ & $\begin{array}{l}\text { Chinese leek } \\
\text { Red cabbage } \\
\text { Water dropwort } \\
\text { Garland chrysanthemum } \\
\text { Flower stalk } \\
\text { Welsh onion } \\
\text { Radish (hatsuka) } \\
\text { Lotus } \\
\text { Summer squash } \\
\text { Taro (kyo-imo) } \\
\text { Melon } \\
\text { Lime } \\
\text { Kabosu } \\
\text { Peach } \\
\text { Akebia } \\
\text { Shiitake } \\
\text { Mekabu }\end{array}$ & $\begin{array}{l}\text { Japanese butterbur } \\
\text { Kaiware radish } \\
\text { Turnip leaf } \\
\text { Shantung green } \\
\text { Garlic } \\
\text { Royal fern } \\
\text { Wasabi } \\
\text { Tomato } \\
\text { Tomapea } \\
\text { Taro (oya-imo) } \\
\text { Orange } \\
\text { Pummelo } \\
\text { Summer orange } \\
\text { Prune } \\
\text { Pineapple } \\
\text { Shimeji } \\
\text { Wakame }\end{array}$ \\
\hline
\end{tabular}

Anti-OA activity, Very strong (++): over $80 \%$, Strong (+): from $40 \%$ to $79 \%$, Weak ( \pm ): from $20 \%$ to $39 \%$, None (-): less than $19 \%$. 
Table 3. Change in anti-OA activity by heat treatment.

\begin{tabular}{lcc}
\hline & Fresh & Boiled \\
\hline Basil & ++ & - \\
Peppermint & ++ & - \\
Broccoli & ++ & - \\
Tomyo & + & - \\
Cabbage & + & + \\
Watermelon & ++ & - \\
Edible burdock & ++ & ++ \\
Winter fungus & ++ & \pm \\
Oyster mushrooms & + & - \\
Cultivated mushrooms & + & - \\
\hline
\end{tabular}

Anti-OA activity, Very strong (++): over $80 \%$, Strong (+): from $40 \%$ to $79 \%$, Weak $( \pm)$ : from $20 \%$ to $39 \%$, None $(-)$ : less than $19 \%$.

Table 4. Anti-OA activities of the fractions from freeze dried samples that showed strong activity.

\begin{tabular}{lccccc}
\hline & Hexane & Benzene & Ethyl acetate & Methanol & Water \\
\hline Broccoli & ++ & - & - & - & \pm \\
Edible burdock & ++ & + & - & - & ++ \\
Cabbage & ++ & ++ & + & + & ++ \\
Cultivated & - & - & - & - & - \\
$\quad$ mushrooms & & - & \pm & - & + \\
Pumpkin & - & - & \pm & - & ++ \\
Eggplant & - & - & \pm
\end{tabular}

Anti-OA activity, Very strong (++): over $80 \%$, Strong (+): from $40 \%$ to $79 \%$, Weak $( \pm)$ : from $20 \%$ to $39 \%$, None (-): less than $19 \%$.

(100\%) and cabbage (55\%) showed activity following this treatment, and winter fungus (37\%) showed weak activity, but the other plants showed none.

These findings indicate that only edible burdock shows component stability through the processes of cold storage and boiling. Winter fungus, cabbage and basil maintained component stability in either process.

The solubility of the active components To fractionate the active components, 6 freeze dried samples that showed activity were extracted with 10 volumes of several different solvents for $20 \mathrm{~min}$, and then each resulting extract was evaporated to dryness. The solvents used were hexane, benzene, ethyl acetate and methanol in order of polarity. After extraction with the first solvent three times, the residue was successively extracted with the next solvent. After each resulting extract was dissolved at a suitable concentration in DMSO, it was suspended in the buffer solution, and subjected to assay of anti-OA activity.

In the water-soluble fraction, edible burdock (83\%), eggplant $(80 \%)$, cabbage $(85 \%)$ and pumpkin $(63 \%)$ showed strong activity, as shown in Table 4, while cabbage, edible burdock and broccoli also showed strong activity in low polarity fractions like hexane. Notably, cultivated mushrooms showed no activity in any fraction, nor was activity seen in any mixture of them.

Furthermore, the activity in each solvent fraction following heating of cabbage and edible burdock, which showed activity after the heat treatment was examined. Although differences were apparent, the activity was present in each solvent fraction (Table 5). Representative water-soluble components such as ascorbic acid, thiamin and cystein that were contained in strong activity samples were tested (Science \& Technology Agency, 1998). The anti-OA activity of ascorbic acid ( $1 \mathrm{mg} / \mathrm{ml})$ was $15 \%$, cystein $(1 \mathrm{mg} / \mathrm{ml})$ was $27 \%$ and thiamin $(1 \mathrm{mg} / \mathrm{ml})$ was $18 \%$. All
Table 5. Anti-OA activities of the fractions from boiled samples that showed strong activity.

\begin{tabular}{lccrccc}
\hline & \multicolumn{2}{c}{ Cabbage } & & \multicolumn{2}{c}{ Edible burdock } \\
\cline { 2 - 3 } \cline { 6 - 7 } & Fresh & Boiled & & Fresh & Boiled \\
\hline Hexane & ++ & + & & ++ & + \\
Benzene & ++ & + & & + & ++ \\
Ethyl acetate & + & \pm & & - & - \\
Methanol & + & + & & - & - \\
Water & ++ & \pm & & ++ & ++ \\
\hline
\end{tabular}

Anti-OA activity, Very strong (++): over $80 \%$ Strong (+): from $40 \%$ to $79 \%$ Weak ( \pm ): from $20 \%$ to $39 \%$ None $(-)$ : less than $19 \%$.

these water-soluble standards showed weak activity. The dietary fiber in these foods was also tested. For these edible plants which showed the activity, the active components may exist except for these standard substances. In the future, we will use purification techniques to clarify the chemical structure of the active components.

Acknowledgement This study was supported by a science subsidy from the Iijima Foundation.

\section{References}

Fujiki, H. (1992). Is the inhibition of protein phosphatase 1 and $2 \mathrm{~A}$ activities a general mechanism of tumor promotion in human cancer development? Mol. Carcinogenesis, 5, 91-94.

Fujiki, H. and Suganuma, M. (1999). Unique features of the okadaic acid activity class of tumor promoters. J. Cancer Res., Clin. Oncol., 125(3/4), 150-155.

Kanazawa, K., Kawasaki, H., Samejima, H., Ashida, H. and Danno, G. (1995). Specific desmutagen (antimutagen) in oregano against a dietary carcinogen, Trp-P-2, are galangin and quercetin. J. Agric. Food Chem., 43, 404-409.

Koshimizu, K. (1995). Investigation and analysis of anti-tumor promoter in edible plants. In "Kinousei Shokuhin no Kenkyuu," ed. by S. Arai. Gakkai Shuppan Center, Tokyo (in Japanese).

Koshimizu, K. (1996). The food which can the prevent cancer and aging. Presented at 28th Symposium on Nippon Shokuhinkagaku Kougakkai Kansai Shibu, Kyoto, December 6, pp. 11-14 (in Japanese).

Matias, W.G., Traore, A. and Creppy, E.E. (1999). Variations in the distribution of okadaic acid in organs and biological fluids of mice related to diarrhetic syndrome. Hum. Exp. Toxicol., 18, 345-350.

Murata, M., Shimatani, M., Sugitani, H., Oshima, Y. and Yasumoto, T. (1982). Isolation and structural elucidation of the causative toxin of the diarrhetic shellfish poisoning. Bull. Jpn. Soc. Sci. Fish, 48, 549552.

Nakamura, R., Kawagishi, S., Watanabe, K. and Osawa, T. (1990). "The functional food science (Shokuhin Kinou Kagaku)." Sankyo Shuppan Co., LTd., Tokyo.

Natake, M., Kanazawa, K., Mizuno, M., Ueno, N., Kobayashi, T., Danno, G. and Minamoto, S. (1989). Herb water-extracts markedly suppress the mutagenicity of Trp-P2. Agric. Biol. Chem., 53, 14231425 .

Ogino, H., Sakamoto, H. and Ishiguro, Y. (1997). Screening for anti tumor-promoters in vegetable-juices. Nippon Eiyou Shokuryou Gakkaishi, 50, 51-56 (in Japanese).

Ohara, A., Mizuno, M., Danno, G., Kanazawa, K., Yoshioka, T. and Natake, M. (1988). Mutagen formed from tryptophan reacted with sodium nitrite in acidic solution. Mutat. Res., 206, 65-71.

Ohara, A. and Hiramatsu, N. (1997). Antimutagenic activity in extracts of plant foods. Nippon Kasei Gakkaishi, 48, 637-642 (in Japanese).

Ohara, A. and Takehara, M. (1997). Antimutagenic activities of Eugeniin. Nippon Eiyou Shokuryou Gakkaishi, 50, 372-375 (in Japanese).

Ohara, A, Matsuhisa, T. and Mori, K. (2000). Antimutagenicity of 
herbs and spices used as "Yakumi" against different mutagens. $J$. Home Econ. Jpn, 51, 725-729.

Ohigashi, H., Murakami, A., Nakamura, Y. Koshimizu, K. (1997). "Anti-tumor Promoters from Edible Thai Plants: Isolation, Cancer Preventive Potential, and Action Mechanisms." Food Factors for Cancer Prevention, Hamamatsu, 188-193.

Osawa, T. (1995). "Recent Development of Food Phytochemicals for Cancer Prevention." CMC, Tokyo (in Japanese).

Osawa, T. (1999). Designer foods and functional foods. In "The Cancer Prevention Food (Gan Yobou Shokuhin).” ed. by Osawa, T., Ohigashi, H. and Yoshikawa, T. CMC, Tokyo (in Japanese).

Samejima, K., Kanazawa, K., Ashida, H. and Danno, G. (1995). Luteolin: A strong antimutagen against dietary carcinogen, Trp-P-2, in peppermint, sage, and thyme. J. Agric. Food Chem., 43, 410-414.

Science and Technology Agency. (1998). "Standard tables of food composition in Japan.” Kagawa Nutrition Coll. publication division, Tokyo.

Suganuma, M. and Fujiki, H. (1993). The chemical prevention of the human carcinogenesis by EGCG. Nippon Nougeikagaku Kaishi, 67, 35-37 (in Japanese).
Sugimura, T. (1982). "Carcinogens.” Chukou Shin-sho, Tokyo (in Japanese).

Sugimura, T. (1995). Mutagenicity and carcinogenicity of heterocyclic amines. Environ. Mut. Res. Commun., 17, 7-21 (in Japanese).

Takai, A. and Mieskes, G. (1991). Inhibitory effect of okadaic acid on the p-nitrophenyl phosphate phosphatase activity of protein phosphatases. Biochem. J., 275, 233-239.

Takai, A., Murata, M., Torigoe, K., Isobe, M., Mieskes, G. and Yasumoto, T. (1992). Inhibitory effect of okadaic acid derivatives on protein phosphatases. Biochem. J., 284, 539-544.

Traore, A., Ruiz, S., Baudrimont, I., Sanni, A. Dano, S.D., Guarigues, Ph. Narbonne, J.F. and Creppy, E.E. (2000). Combined effects of okadaic acid and cadmium on lipid peroxidation and DNA bases modification ( $\mathrm{m} 5 \mathrm{dC}$ and $8-(\mathrm{OH})-\mathrm{dG})$ in Caco-2 cells. Arch. Toxicol., 74, 79-84.

Watanabe, S., Uehara, M., Kimira, M., Yamano, Y. and Sasaki, R. (1997). Cancer Prevention. In "Free Radicals and Disease Prevention," ed. by T. Yoshikawa, O. Igarashi and Y. Itokawa. Kenpakusha, Tokyo, pp. 127-184 (in Japanese). 